\title{
PHYTOREMEDIATION OF SALT- AFFECTED SOILS AT AL- JAZEERA NORTHERN IRRIGRATION PROJECT/ NINAVAH/IRAQ
}

\author{
Amer W. Abdul-Kareem \\ Khalid Ekhlayef Nazzal \\ Soil and Water Resources Science.College of Agriculture/Forestry.University of \\ Mosul/Iraq
}

E-mail:amer-waddie@yahoo.com

\section{ABSTRACT}

Soil salinity is one of the most serious limiting factors that affect plant growth and productivity of various crops in arid regions. Methods commonly used to combat salinity are either classical or new using halophytes.This study was conducted at plastichouse in order to evaluate the efficiency of Atriplexhalimus in salt removal from saline, saline-sodic soils of Al-jazeera project in Ninavah province. Plantation with A.halimus decreased electrical conductivity for saline- sodic soil from 39.2 to $26.5 \mathrm{dS} . \mathrm{m}^{-1}$ and from 6.2 to $4.9 \mathrm{dS} . \mathrm{m}^{-1}$ for saline soil. Sodium adsorption ratio declined to half and $28.6 \%$ for saline- sodic and saline soils respectively. The current study revealed an increased efficiency of Atriplexhalimus with increasing salinity which suggest it a good candidate for soil desalination in arid and semiarid regions.

Keywords: Phytoremdeiation, Salinity, Atriplex, SAR .

Recived: 19/2/2012 Accepted 30/4/2012

\section{INTRODUCTION}

Salinity and sodicity are among the main causes of land degradation that retards plant growth and productivity worldwide (Qadir\& Schubert, 2002), and affects roughly $7 \%$ of the words total land area, particularly in arid and semi-arid regions. Such an extensive area emphasizes the need for efficient inexpensive and environmental acceptable management strategies to enhance crop productively and sustainability of the ecosystems. There are two major approaches to the problem of salinized soils, (i) control of salinity level by soil, water and crop management practices and/ or (ii) biological or genetic management through the use of high salt tolerant species( Pastemak,1987) . Leaching salts from the root zone usually requires large amounts of water.In a country like Iraq where the availability of fresh water is becoming a serious problem, this method is not recommended. The utilization of halophytes in salt-affected soils in arid and semi- arid regions is the only economic solution presently available for soil reclamation. (khan and Duke, 2001). Atriplex constitutes an essentially cosmopolitan genus of more than 417 species (Osmond etal. 1980). Atriplexhalimus is a perennial native shrub with an excellent tolerance to drought and salinity (Ortiz- drodaetal. 2005).Boyko (1964) was the first to suggest that halophytic plants could be used to desalinate soil and water. In Iraq, studies on phytoremediation are very scarce and concentrated on using halophytes to tolerate aridity and in recent years an agreement was established between Iraqi Ministry of Agriculture, ICARDA and University of Mosul within a soil preservation agriculture program.

Part of M.Sc. thesis for the $2^{\text {nd }}$ author 
Mesopotamia J. of Agric. Vol. (41) No. (3) 2013
ISSN: 2224-9796 (Online)

ISSN: $1815-316 \mathrm{X}$ (Print)
مجــلـة زر اعــــة الر افـديــن

المجلد (41) العدد (3) 2013

Accordingly, three Atriplex species namely A. halimus, A. nummularia and A. canseces were entered Iraq and employed in an agricultural program atNinavah province to tolerate aridity and their value as a livestock forage crops. The aim of this study was to investigate salt removal from salt- affected soils at Al- jazeera northern irrigation project/ Ninavah, cultivated with Atriplexhalimus.

\section{MATERIALS AND METHODS}

Atriplex halimus was selected among four Atriplex species (A. halimus, A. nummularia, A. canseces and A. leucoclada) from a previous experiment (not published) using more closely related indices of identifying salt tolerant plants. Soil samples were collected from two irrigation units ,saline soils (G10) and salinesodic soils (N16) of Al- jazeera project at Rabia district of Ninavah Province. They were collected from $0-30 \mathrm{~cm}$ depth, dried in air, homogenized and passed through a sieve of $2 \mathrm{~mm}$ before filling the pots with a capacity of $6 \mathrm{~kg}$ of dry soil. Some general chemical and physical characteristics of the soils are shown in table(1). The experiment was carried out in a plastic house which lasted for ninty days with four replicates for each soil and one plant per pot . Soil samples were also analyzed for specific parameter at the start and the end of the experiment on samples collected randomly from several depths of the pots like electrical conductivity, soluble sodium, calcium, magnesium and chorideusing standard procedures outlined by Tandon (1999). Sodium adsorption ratio (SAR), was calculated from concentrations of cations $\left(\right.$ mmol $\left._{\mathrm{c}} \cdot \mathrm{l}^{-1}\right)$ in the extract by the equation:

$$
\mathrm{SAR}=\frac{\mathrm{Na}}{\sqrt{\frac{\mathrm{Ca}+\mathrm{Mg}}{2}}}
$$

Plant received tap water, divided in upper parts and rootsat the end of the experiment, oven dried at $65^{\circ}$ for $48 \mathrm{~h}$ : The dried plant material was subjected to wetted digestion with a $4: 9(\mathrm{~V}: \mathrm{V})$ sulphuric- perchloric acid mixture as described by Tandon (1999). $\mathrm{Na}^{+}$and $\mathrm{K}^{+}$were determined in the extract by flame photometer. $\mathrm{Cl}^{-}$was measured by titration against $\mathrm{AgNo}_{3}$. (Richards, 1954). $\mathrm{Ca}^{++}$and $\mathrm{Mg}^{++}$by EDTA titrimetry (Lanyon and Heald, 1982). The results were analyzed through variance analysis and L.S.D test $(\mathrm{p}<0.005)$ using theGenstat program.

Table(1): Some chemical and physical properties of the studied soils.

\begin{tabular}{|c|c|c|c|}
\hline \multirow{2}{*}{\multicolumn{2}{|c|}{ Parameter }} & \multicolumn{2}{|c|}{ location } \\
\hline & & $\begin{array}{c}\text { Saline-Sodic Soil } \\
\text { (N16) }\end{array}$ & Saline Soil (G10) \\
\hline & & 7.2 & 7.8 \\
\hline \multicolumn{2}{|c|}{$\mathrm{EC}\left(\mathrm{dS} \cdot \mathrm{m}^{-1}\right)$} & 39.2 & 6.2 \\
\hline $\mathrm{CaCo}_{3}$ & \multirow{6}{*}{$\mathrm{gm} \cdot \mathrm{kg}^{-1}$} & 155 & 189 \\
\hline Organic matter & & 16.0 & 18.6 \\
\hline Sand & & 320 & 250 \\
\hline Silt & & 475 & 625 \\
\hline Caly & & 205 & 125 \\
\hline Texture & & Loam & Silt loam \\
\hline
\end{tabular}




\section{RESULTS AND DISCUSSION}

Some selected properties of the studied soils before and after the end of halophyte plantation are shown in table (2). It is clear the EC values were reduced from 39.2 $\mathrm{dS} . \mathrm{m}^{-1}$ to $26.5 \mathrm{dS} . \mathrm{m}^{-1}$ for saline-sodic soil with a percentage decrease of $32.4 \%$. The corresponding figures for saline soil are 6.2 to $4.9 \mathrm{dS} . \mathrm{m}^{-1}$ and $21 \%$.SAR is an important parameter to understand the equilibrium between soluble salts and exchangeable cations, also declined to half its original value for calcareous salinesodic soil and from 2.1 to $1.5(\mathrm{mmol} / \mathrm{l})^{1 / 2}$ with a percentage decrease of $28.6 \%$ for saline soil. $\mathrm{Na}^{+}$and $\mathrm{Cl}^{-}$concentration decreased from 250 and 372 mmol $_{\mathbf{c}}{ }^{-1}$ to 119 and 234 mmolcl- $^{-1}$ at the end of the experiment for saline-sodic soil. For saline soil, they decreased from 10 and $47 \mathrm{mmol}_{\mathbf{c}} \mathrm{l}^{-1}$ to 7 and $45 \mathrm{mmol}_{\mathbf{c}} \mathrm{l}^{-1}$ for sodium and chloride respectively. Concerning $\mathrm{NaCl}$ removal from the soil, it is clear from table (2) that $\mathrm{NaCl}$ removed from the soil ranged between $3052 \mathrm{Kg} / \mathrm{ha}$ for saline- sodic soil to $70 \mathrm{Kg} / \mathrm{ha}$ for saline soil throught the period of the experiment.

Table (2): Some chemical properties of salt- effected soils before planting and after harvesting A. halimus.

\begin{tabular}{|c|c|c|c|c|c|c|c|c|}
\hline \multirow{3}{*}{ location } & \multicolumn{4}{|c|}{ Before planting } & \multicolumn{4}{|c|}{ After harvesting } \\
\hline & \multirow{2}{*}{$\begin{array}{c}\mathrm{EC} \\
\mathrm{dS} \cdot \mathrm{m}^{-1}\end{array}$} & \multirow{2}{*}{$\begin{array}{c}\text { SAR } \\
(\mathrm{mmol} / \mathrm{l})^{1 / 2}\end{array}$} & $\mathrm{Na}^{+}$ & $\mathrm{Cl}^{-}$ & \multirow{2}{*}{$\begin{array}{c}\mathrm{EC} \\
\mathrm{dS} \cdot \mathrm{m}^{-1}\end{array}$} & \multirow{2}{*}{$\begin{array}{c}\text { SAR } \\
(\mathrm{mmol} / \mathrm{l})^{1 / 2}\end{array}$} & $\mathrm{Na}^{+}$ & $\mathrm{Cl}^{-}$ \\
\hline & & & $\mathrm{mm}$ & $\mathrm{l}_{\mathrm{c}}^{-1}$ & & & \multicolumn{2}{|c|}{$\mathrm{mmol}_{\mathrm{c}}^{-1}$} \\
\hline N16 & 39.2 & 30.4 & 250 & 372 & 26.5 & 15.2 & 119 & 234 \\
\hline G10 & 6.2 & 2.1 & 10 & 47 & 4.9 & 1.5 & 7 & 45 \\
\hline
\end{tabular}

The sharp decrease in salinity was reflected in the highest concentration in the halophyte at the end of the experiment as shown in table (3) especially for $\mathrm{Na}^{+}$and $\mathrm{Cl}^{-}$ions concentration as it reached 40.98 and $71 \mathrm{mg} \cdot \mathrm{gm}^{-1}$ dry weight for saline- sodic soil and $23.38,42.6 \mathrm{mg}_{\mathrm{gm}}{ }^{-1}$ for saline soil. Statistical analysis revealed that the main ion concentration with the exception of $\mathrm{K}^{+}$were significant between saline- sodic and saline soils for the upper part and for $\mathrm{Na}^{+}$and $\mathrm{Cl}^{-}$for the roots. The efficiency of Atriplex halimus for salt removed increased with increasing salinity especially for calcareous- sodic soils. As outlined by Qadiretal. (2005) where they found that phytoextraction is driven by (i) enhanced $\mathrm{Na}^{+}$and salt uptake in the shoots and at harvest (ii) ability of plant roots to increase the dissolution rate of calcite, resulting in enhanced levels of $\mathrm{Ca}^{++}$in soil solution to replace $\mathrm{Na}^{+}$from the cation exchange complex. This process is enhanced by the pressure of $\mathrm{CO} 2$ within the root zone.

The results of the present study are in agreement with those reported by Al-Nasir (2009) in Jordan, Saritaetal. (2008) for various salt hyperaccumulator plant in india and in Egypt for forage production using halophytes (Ashouretal. 1999) and salt removed by Atriplex halimus (Anonymous, 2003). 
Mesopotamia J. of Agric.

Vol. (41) No. (3) 2013
ISSN: 2224-9796 (Online) ISSN: $1815-316$ X (Print)

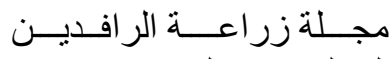

المجلد (41) العدد (3) 2013 أر

Table(3): Dry and fresh weight, ion concentration in shoots and roots of Atriplex halimus at the end of experiment.

\begin{tabular}{|c|c|c|c|c|c|c|c|c|}
\hline \multirow[t]{2}{*}{ Soil type } & \multirow{2}{*}{$\begin{array}{l}\text { Plan } \\
\text { part }\end{array}$} & $\mathrm{Mg}^{++}$ & $\underset{+}{\mathrm{Ca}^{+}}$ & $\mathrm{K}^{+}$ & $\mathrm{Na}^{+}$ & $\mathrm{Cl}^{-}$ & $\begin{array}{l}\text { Fresh } \\
\text { weight }\end{array}$ & $\begin{array}{c}\text { Dry } \\
\text { weight }\end{array}$ \\
\hline & & \multicolumn{5}{|c|}{$\mathrm{mg} \cdot \mathrm{g}^{-1}$} & \multicolumn{2}{|c|}{$\mathrm{gm}$} \\
\hline $\begin{array}{l}\text { Saline-Sodic } \\
\text { soil(N16) }\end{array}$ & \multirow{2}{*}{ Shoots } & 21.25 & 8.25 & 33.80 & 40.98 & 71.00 & 24.00 & 7.26 \\
\hline $\begin{array}{c}\text { Saline } \\
\text { soil(G10) }\end{array}$ & & 18.75 & 5.25 & 32.10 & 23.38 & 42.6 & 85.70 & 22.13 \\
\hline \multicolumn{2}{|c|}{ L.S.D 0.05} & 0.86 & 0.86 & 7.62 & 4.34 & 3.69 & 15.14 & 3.47 \\
\hline $\begin{array}{c}\text { Saline-sodic } \\
\text { soil(N16) }\end{array}$ & \multirow[t]{2}{*}{ Roots } & 10.50 & 4.50 & 11.73 & 3.67 & 53.25 & 5.80 & 2.17 \\
\hline $\begin{array}{c}\text { Saline } \\
\text { soil }(\mathrm{G} 10)\end{array}$ & & 10.75 & 4.50 & 17.63 & 2.01 & 35.5 & 16.86 & 6.86 \\
\hline \multicolumn{2}{|l|}{ L.S.D 0.05} & 0.39 & 0.99 & 3.82 & 0.70 & 3.50 & 8.46 & 2.27 \\
\hline
\end{tabular}

المعالجة البايولوجية للترب المتأثرة بالأملاح في مشروع ري الجزيرة الثمالي/ نينوى/ العراق

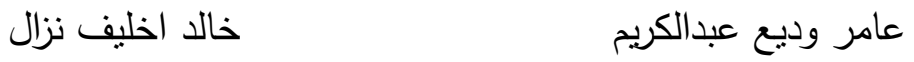

قسم علوم التربة والموارد المائية / كلية الزراعة والغابات /جامعة الموصل

amer-waddie@yahoo.com

\section{الخلاصة}

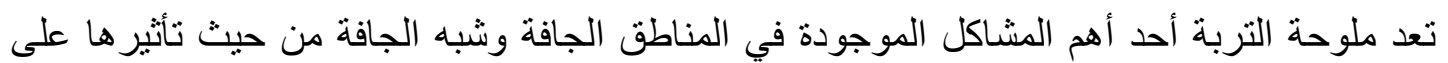

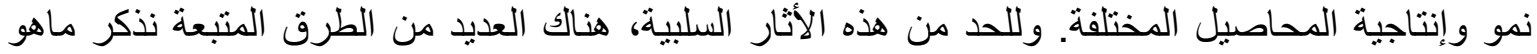

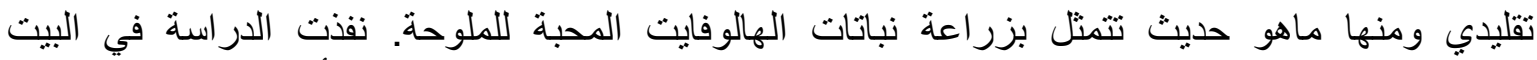

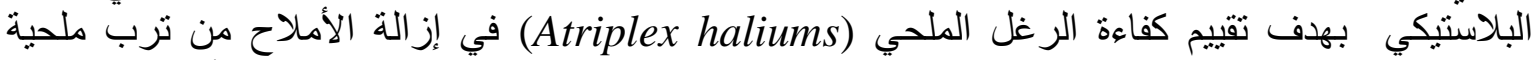

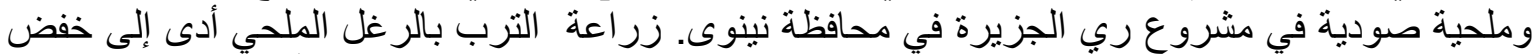

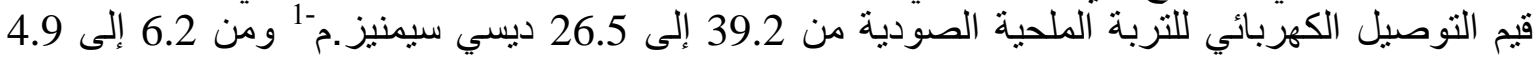

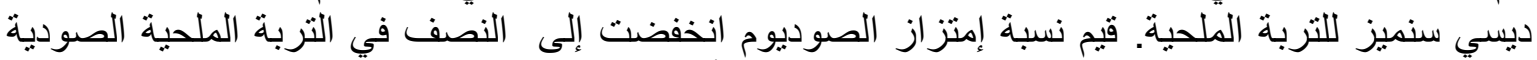

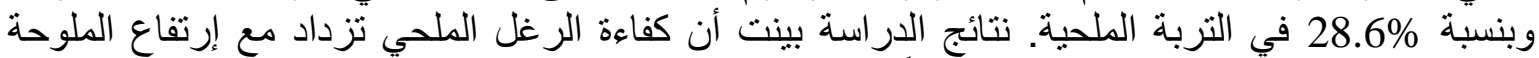

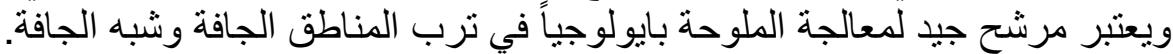

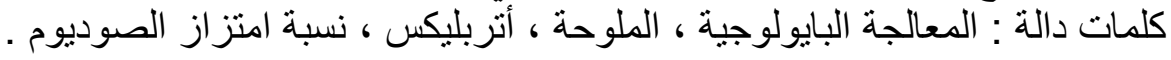

تاريخ تسلم البحث:2/19/ 2012 وقبوله 30 /4/ 2012

\section{REFERENCE}

Al- Nasir F. (2009). Bioreclamation of a saline- sodic soil in a semi-arid region/ Jordan. American Eurasian Journal Agricultural and Environmental Science. 5: 701- 706. 
Mesopotamia J. of Agric.

Vol. (41) No. (3) 2013
ISSN: 2224-9796 (Online) ISSN: $1815-316$ X (Print)

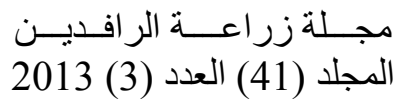

Anonymous (2003). Find Report Salt Control Project. Control of Salinization and Combating Desertification Effects In the Mediterranean Region: 1-70.

Ashour, N., S.M. Arafact, A. Abd Eh- Haleem, M. Serag, S. Mandor and B. Kekki (1999). Growing halophytes in Egypt for forage production and desertification control. Bulletin of Natural Resource Council, Egypt, 24(3): 349- 360 .

Boyko H.(1964). Basic ecobgical principles of plant growing by irrigation with high saline seawater. In: Boyko, H.(Ed.), Salinity and Aridity. D.W. Junk Publisher, The Huge.

Khan, M.A. and N.C. Duke (2001). Halophytes- A resource for the future. Wetlands Ecology and Management. 6:455- 456.

Lanyon, Les E. and W.R. Heald (1982). Magnesium, Calcium, Strontium and Batrium. In A.L. Page (ed.) Methods of Soil Analysis. Agronomy 9: 247262. Am. Soc. Of Agronomy, Inc., Madison, Wisconson.

Ortiz- Dorda, J., C. Martinez- Mora, E. Correal, B. Simon and J.L. Cenis (2005). Genetic structure of Atriplex halimus population in the Mediterranean Basin. Annual Journal of Botany, 95: 827- 834.

Osmond, CB, O. Bjorkman and D.J Anderson. (1980) Physiological Processes in Plant Ecology: Towards a Synthesis with Atriplex. Springer- Verlag, Berlin.

Pastemak, D. (1987). Salt tolerance and crop production. A comprehensive approach. Annual Review Phytopathology, 25: 271.

Qadir M. \& S. Schubert (2002). Degradation processes and nutrient constraints in sodic soil. Land Degradation and Development, 13: 275- 294.

Qadir M., A.D. Noble, J.D. Oster, S. Schubert \& A Ghafoor. (2005) Driving forces for sodium removed during phytoremediation of calcareous sodic and salinesodic soils: a review. Soil use and Management. 21, 173-180.

Richards L.A. (1954). Diagnosis and Improvement of Saline and Alkali Soils. United States Government Printing office, Washington, Handbook No. 60.

Sarita, Devi, RaniC., Datta K.S, Bishnoi S.K., Mahala S. C., R. Angrish. (2008). Phytoremediation of soil salinity using salt hyperaccumulator plants. Indian Journal of plant physiology. 13(4): 226-236.

Tandon, HLS (1999). Methods Analysis of Soils, Plants, Waters and Fertilizers Fertiliser Development and Consultation Organisation. New Delhi. 